\title{
The influence of homoeologous $D(A)$ and $D(B)$ substitutions on plant dry matter, nitrogen and phosphorus accumulation and utilization efficiency in hexaploid triticale young plants grown in hydroponics
}

\author{
Wpływ homeologicznych substytucji $D(A)$ i $D(B)$ w siewkach heksaploidalnego \\ pszenżyta na gromadzenie suchej masy, akumulację oraz wykorzystanie azotu i \\ fosforu w kulturze hydroponicznej
}

\section{Teresa Oracka, Zbigniew Rybka ${ }^{\bowtie}$, Bogusław Łapiński}

Plant Breeding and Acclimatization Institute, Radzików, 05-870 Błonie

$\bowtie$ e-mail: z.rybka@ihar.edu.pl

\begin{abstract}
The accumulation and utilization efficiency of nitrogen and phosphorus were studied using hydroponic cultures of seedlings of the 'Presto' and 'Rhino' $\mathrm{D}(\mathrm{A})$ and $\mathrm{D}(\mathrm{B})$ substitution lines of hexaploid triticale. The results were significantly affected by homoeology group of chromosomes participating in a substitution, the A or B genome origin of replaced chromosome and genetic background of triticale cultivar. The substitutions $4 \mathrm{D}(4 \mathrm{~B})$ and $5 \mathrm{D}(5 \mathrm{~B})$ resulted in an increase of plant dry matter in relation to the non-substituted cultivars. The significant increase of $\mathrm{N}$ accumulation was found in $3 \mathrm{D}(3 \mathrm{~A})$ and $4 \mathrm{D}(4 \mathrm{~B})$ of 'Rhino', and $5 \mathrm{D}(5 \mathrm{~B})$ and $4 \mathrm{D}(4 \mathrm{~B})$ of 'Presto'. The improvement of $\mathrm{N}$ utilization efficiency was recorded for $2 \mathrm{D}(2 \mathrm{~A})$ and $1 \mathrm{D}(1 \mathrm{~B})$ of 'Presto', and $5 \mathrm{D}(5 \mathrm{~B}), 7 \mathrm{D}(7 \mathrm{~A})$ and $5 \mathrm{D}(5 \mathrm{~A})$ of 'Rhino'. The $\mathrm{P}$ accumulation was distinctly improved in 'Presto' $5 \mathrm{D}(5 \mathrm{~B})$ substitution. The P utilization efficiency was improved in all substitutions containing $4 \mathrm{D}$ or $6 \mathrm{D}$ as well as in 'Presto' $2 \mathrm{D}(2 \mathrm{~B})$ and $5 \mathrm{D}(5 \mathrm{~B})$.
\end{abstract}

Key words: breeding, D-genome, $\mathrm{N}$ accumulation, $\mathrm{N}$ utilization efficiency (NUE), P accumulation, $\mathrm{P}$ utilization efficiency (PUE), substitution lines, triticale

Badano akumulację i efektywność wykorzystania azotu i fosforu w warunkach kultury hydroponicznej w siewkach linii substytucyjnych $\mathrm{D}(\mathrm{A})$ i $\mathrm{D}(\mathrm{B})$ heksaploidalnego pszenżyta odmian Rhino i Presto. Obecność substytucji chromosomów grupy D przy zachowaniu w całości genomu żytniego $(\mathrm{R})$ istotnie zmieniała gospodarkę mineralną siewek. Obecność substytucji 4D(4B) i 5D(5B) powodowała zwiększenie suchej masy siewek w porównaniu do siewek bez substytucji. Obserwowano zwiększenie akumulacji azotu w siewkach odmiany Rhino z substytucjami 3D(3A) i 4D(4B) oraz odmiany Presto z substytucjami 5D(5B) and 4D(4B). Zwiększenie wykorzystania azotu zaobserwowano w substytucjach $2 \mathrm{D}(2 \mathrm{~A})$ and $1 \mathrm{D}(1 \mathrm{~B})$ odmiany Presto i w substytucjach 5D(5B), 7D(7A) i 5D(5A) odmiany Rhino. Akumulacja fosforu była istotnie zwiększona w siewkach odmiany Presto z substytucją 5D(5B). Wykorzystanie fosforu było znacznie wyższe w siewkach obu odmian zawierających substytucje chromosomów 4D i $6 \mathrm{D}$ oraz w siewkach odmiany Presto z substytucjami 2D(2B) i 5D(5B).

Słowa kluczowe: akumulacja azotu, akumulacja fosforu, genom D, hodowla, linie substytucyjne, pszenżyto, wykorzystanie azotu (NUE), wykorzystanie fosforu (PUE)

\section{Introduction}

Breeding of plants efficient in absorption and utilization of nutrients is an undervalued tool to improve efficiency of applied fertilizers, to reduce input costs and to prevent leaks of nutrients to the ecosystem. Large differences among species and cultivars in absorption, translocation and utilization of mineral nutrients are known (Baligar et al. 2001). Due to multigenic character of nutrient metabolism the control or manipulation of genes involved is difficult and results are unpredictable.
A simpler way to improve nutrient metabolism in alloploid cereals is manipulation on the chromosomal level using substitutions or translocations, which can result in efficiency of mineral fertilization (Górny 2000).

The hexaploid triticale (xTriticosecale Wittmack, genome formula AABBRR), due to presence of rye genome (R), is a species showing remarkable improvement in accumulation of nitrogen and phosphorus as compared to wheat (Triticum aestvum L. - AABBDD) 
(Ciepły and Oracka 2001, Paponov et al. 1999). On the other hand, according to Huang et al. (2007), the D-genome of common wheat, which has not been included to hexaploid triticale, also contains valuable genes controlling utilization of mineral nutrients. Our earlier studies (Oracka, Lapiński, 2006) on two sets of $\mathrm{D}(\mathrm{R})$ substitution lines of hexaploid triticale revealed a positive influence of almost all substituting D genome chromosome pairs on the efficiency of use of the absorbed nitrogen and phosphorus. Therefore a question appears on a possibility to combine the positive effects of R- and D- genomes' chromosomes in a single hexaploid triticale karyotype. Among the existing cytogenetic stocks, the $\mathrm{D}(\mathrm{A})$ and $\mathrm{D}(\mathrm{B})$ substitution lines of triticale give opportunity to investigate effects of particular D-genome chromosomes on traits of plants containing whole rye genome. We assessed the influence of these substitutions on dry matter, nitrogen and phosphorus accumulation and utilization efficiency in young triticale plants grown in hydroponic medium with reduced concentration of nutrients.

\section{Material and Methods}

The material consisted of two sets of disomic $\mathrm{D}(\mathrm{A})$ and $\mathrm{D}(\mathrm{B})$ substitution lines, derived from the hexaploid triticale cultivars 'Presto' (winter) and 'Rhino' (spring) (Lukaszewski, 1990). Both sets contained all possible homoeological substitutions of wheat $\mathrm{D}$ genome chromosomes for their A or B genome counterparts, except for the 7D (7B) in 'Rhino'. The non-substituted cultivars 'Presto' and 'Rhino' were used as controls.

The procedures of seed germination and planting, growth chamber parameters and the medium composition had been described in our earlier paper (Oracka and Łapiński, 2005). Seedlings were kept in $4^{\circ} \mathrm{C}$ for 30 days and then planted on plastic tanks containing 401 of the modified Hoagland no. 2 solution (Hoagland,and Arnon, 1950) at 50\% reduced level of mineral elements. The plants were grown in a growth chamber supplied with the fluorescent lamps (MASTER TLD 58W/865, PHILIPS), at irradiance of $350 \mathrm{mmol} \mathrm{m}^{2} \mathrm{~s}^{-1}$ and $16 \mathrm{~h}$ day length. The nutrient solution was aerated for 10 minutes every hour and renewed every 4 days. The temperatures were $18^{\circ} \mathrm{C}$ (day) and $13^{\circ} \mathrm{C}$ (night), air humidity was $70 \%$.

The experiment was designed as four replicates of four plants for each line. The plants were harvested after 41 days of growth (shooting stage) and plant dry matter was determined (after drying overnight at $105^{\circ} \mathrm{C}$ ). Standard procedures (Kjeldahl digestion, ammonium molybdate photometry) were used to determine $\mathrm{N}$ and $\mathrm{P}$ content in dry matter. The $\mathrm{N}$ and $\mathrm{P}$ accumulation was calculated from the dry matter and $\mathrm{N}, \mathrm{P}$ concentrations, and the utilization efficiencies (NUE, PUE) were calculated as ratios of plant dry matter to total content of $\mathrm{N}$ or $\mathrm{P}$ in plants.

Analysis of variance (ANOVA) was performed to test the differences between objects for all parameters studied. Significant effects $(\mathrm{P}<0.05)$ were explored using Tukey's LSD procedure.

\section{Results}

The $\mathrm{D}(\mathrm{A})$ and $\mathrm{D}(\mathrm{B})$ chromosome substitutions caused a significant variability of the examined parameters, as shown in Table 1. The differences were dependent on cultivar, chromosome homoeology group and whether A or B genome chromosomes were substituted.

Plant dry matter of the 16 substitution lines was significantly lower than that of the cultivar standards, 9 lines showed a similar level and two ones exceeded significantly the original cultivar. The 'Presto' substitutions were generally more variable than those of 'Rhino'. The lowest 'Presto' group results were recorded for the substitutions $4 \mathrm{D}(4 \mathrm{~A})$ and $1 \mathrm{D}(1 \mathrm{~A})$ and the highest ones for the substitutions $4 \mathrm{D}(4 \mathrm{~B})$ and $5 \mathrm{D}(5 \mathrm{~B})$. The $1 \mathrm{D}(1 \mathrm{~B})$, $2 \mathrm{D}(2 \mathrm{~A}), 3 \mathrm{D}(3 \mathrm{~B}), 4 \mathrm{D}(4 \mathrm{~A})$ and $6 \mathrm{D}(6 \mathrm{~B})$ substitutions negatively affected plant vigor, regardless the acceptor cultivar. The lacking 7D(7B) substitution would also be included to the abovementioned group, as the karyotype inviability on the 'Rhino' genetic background may be considered an extreme case of negative influence. Considering the relation of the substitution lines to their standard cultivars, the $2 \mathrm{D}(2 \mathrm{~B})$ and $5 \mathrm{D}(5 \mathrm{~A})$ on the 'Presto' background performed significantly better than in context of the 'Rhino' chromosomes. On the other hand, the $1 \mathrm{D}(1 \mathrm{~A}), 3 \mathrm{D}(3 \mathrm{~A})$ and $7 \mathrm{D}(7 \mathrm{~A})$ performed better on the 'Rhino' genetic background. The 4D(4B), $5 \mathrm{D}(5 \mathrm{~B})$ and $6 \mathrm{D}(6 \mathrm{~A})$ did not cause significant decrease of plant dry matter in both cultivars.

Nitrogen accumulation: The amount of nitrogen absorbed was usually proportional to the plant dry matter content. The group of lines containing the 4D(4B) and 5D(5B) substitutions of 'Presto' and 3D(3A) 4D(4B) substitutions of 'Rhino' performed significantly better than standards. In relation to dry matter, the 7D(7A) 'Presto' substitution and 'Rhino' $3 \mathrm{D}(3 \mathrm{~B})$ showed increase of $\mathrm{N}$ accumulation.

Nitrogen utilization efficiency (NUE): The variability of NUE was much lower among the studied lines than in dry matter or $\mathrm{N}$ accumulation. However, significant superiority over the standard 
cultivars was noted for the $1 \mathrm{D}(1 \mathrm{~B})$ and $2 \mathrm{D}(2 \mathrm{~A})$ lines the $\mathrm{P}$ accumulation was distinctly lower than of 'Presto' and $5 \mathrm{D}(5 \mathrm{~A}), 5 \mathrm{D}(5 \mathrm{~B}), 7 \mathrm{D}(7 \mathrm{~A})$ of 'Rhino'. in the standard cultivar. The $5 \mathrm{D}(5 \mathrm{~B})$ line was the The lines $6 \mathrm{D}(6 \mathrm{~A})$ and $7 \mathrm{D}(7 \mathrm{~A})$ of both cultivars and $1 \mathrm{D}(1 \mathrm{~A})$ of' Rhino' showed relatively high levels of nitrogen accumulation and efficiency of use, in spite of a negative correlation of these parameters in majority of the lines.

Phosphorus accumulation was highly variable, depending on cultivar and chromosome homoeology group. In majority of the 'Presto' substitution only positive exception, showing significant increase of $\mathrm{P}$ content, in relation to the standard cultivar. No significant decrease has been observed for the 4D(4B) 'Presto' substitution. In the 'Rhino' cultivar the negative effect of the substitutions on $\mathrm{P}$ accumulation was less pronounced and only half of the lines showed significant decrease in $\mathrm{P}$ accumulation, but no line was significantly better.

Table 1

Tabela 1

Effects of D-genome chromosomes' substitutions in the 'Presto' and 'Rhino' triticale cultivars on plant dry matter and on uptake and utilization efficiency of nitrogen and phosphorus (NUE and PUE, respectively), LSD - lowest significant difference, $(+)$ - significantly higher than control.

Wpływ substytucji chromosomów genomu D pszenicy na gromadzenie suchej masy oraz pobieranie i wykorzystanie azotu i fosforu (NUE i PUE) w siewkach pszenżyta odmian Presto i Rhino. LSD - najmniejsza istotna różnica, $(+)$ - wartość istotnie wyższa od kontroli.

\begin{tabular}{|c|c|c|c|c|c|}
\hline $\begin{array}{l}\text { 'Presto' } \\
\text { substitution }\end{array}$ & $\begin{array}{l}\text { Dry matter } \\
{[\mathrm{mg}]}\end{array}$ & $\begin{array}{l}\text { Nitrogen } \\
\text { content } \\
\text { [mg per plant] }\end{array}$ & NUE & $\begin{array}{l}\text { Phosphorus } \\
\text { content } \\
{[\text { mg per plant] }}\end{array}$ & PUE \\
\hline $\begin{array}{l}\text { 'Presto' } \\
\text { non-substituted }\end{array}$ & 748.1 & 24.94 & 30.0 & 7.03 & 102.3 \\
\hline $1 \mathrm{D}(1 \mathrm{~B})$ & 544.6 & 17.83 & $30.6(+)$ & 5.16 & 101.8 \\
\hline $2 \mathrm{D}(2 \mathrm{~A})$ & 459.0 & 16.33 & $31.2(+)$ & 4.53 & 100.6 \\
\hline $2 \mathrm{D}(2 \mathrm{~B})$ & 802.5 & 25.65 & 28.1 & 5.72 & $115.5(+)$ \\
\hline $3 \mathrm{D}(3 \mathrm{~A})$ & 502.0 & 16.61 & 30.2 & 4.70 & 103.5 \\
\hline $3 \mathrm{D}(3 \mathrm{~B})$ & 525.0 & 17.84 & 29.4 & 5.16 & 101.1 \\
\hline $4 \mathrm{D}(4 \mathrm{~A})$ & 351.5 & 11.65 & 30.2 & 3.26 & $104.6(+)$ \\
\hline $4 \mathrm{D}(4 \mathrm{~B})$ & $831.8(+)$ & $28.14(+)$ & 29.6 & 6.72 & $115.8(+)$ \\
\hline $5 \mathrm{D}(5 \mathrm{~A})$ & 743.6 & 26.40 & 28.2 & 6.01 & $107.3(+)$ \\
\hline $5 \mathrm{D}(5 \mathrm{~B})$ & $887.4(+)$ & $30.69(+)$ & 28.9 & $8.03(+)$ & 103.3 \\
\hline $6 \mathrm{D}(6 \mathrm{~A})$ & 699.3 & 23.21 & 30.1 & 5.74 & $109.3(+)$ \\
\hline $6 \mathrm{D}(6 \mathrm{~B})$ & 445.5 & 15.84 & 28.1 & 3.89 & $109.5(+)$ \\
\hline $7 \mathrm{D}(7 \mathrm{~A})$ & 687.1 & 23.78 & 28.9 & 6.07 & 101.8 \\
\hline $7 \mathrm{D}(7 \mathrm{~B})$ & 540.9 & 18.06 & 29.9 & 4.69 & 101.1 \\
\hline LSD & 55.2 & 1.90 & 0.3 & 0.50 & 1.3 \\
\hline $\begin{array}{l}\text { 'Rhino' substi- } \\
\text { tution }\end{array}$ & $\begin{array}{l}\text { Dry matter } \\
{[\mathrm{mg}]}\end{array}$ & $\begin{array}{l}\text { Nitrogen } \\
\text { content [mg } \\
\text { per plant] }\end{array}$ & NUE & $\begin{array}{l}\text { Phosphorus } \\
\text { content [mg } \\
\text { per plant] }\end{array}$ & PUE \\
\hline $\begin{array}{l}\text { 'Rhino' non-sub- } \\
\text { stituted }\end{array}$ & 1391.8 & 47.61 & 29.2 & 14.86 & 93.3 \\
\hline $1 \mathrm{D}(1 \mathrm{~A})$ & 1399.6 & 47.99 & 29.2 & 15.76 & 81.0 \\
\hline $1 \mathrm{D}(1 \mathrm{~B})$ & 1181.7 & 40.41 & 29.2 & 13.81 & 82.8 \\
\hline $2 \mathrm{D}(2 \mathrm{~A})$ & 934.5 & 33.03 & 28.3 & 9.66 & 89.9 \\
\hline $2 \mathrm{D}(2 \mathrm{~B})$ & 1215.8 & 41.98 & 29.0 & 13.04 & 91.7 \\
\hline $3 \mathrm{D}(3 \mathrm{~A})$ & 1475.0 & $52.94(+)$ & 27.9 & 15.79 & 88.9 \\
\hline $3 \mathrm{D}(3 \mathrm{~B})$ & 1253.4 & 43.41 & 28.9 & 13.71 & 84.2 \\
\hline $4 \mathrm{D}(4 \mathrm{~A})$ & 958.4 & 33.37 & 28.7 & 8.38 & $103.7(+)$ \\
\hline $4 \mathrm{D}(4 \mathrm{~B})$ & 1488.4 & $52.15(+)$ & 28.5 & 13.35 & $103.8(+)$ \\
\hline $5 \mathrm{D}(5 \mathrm{~A})$ & 1070.8 & 36.42 & $29.4(+)$ & 11.12 & 93.5 \\
\hline $5 \mathrm{D}(5 \mathrm{~B})$ & 1387.3 & 44.23 & 31.4 & 15.04 & 91.9 \\
\hline $6 \mathrm{D}(6 \mathrm{~A})$ & 1457.9 & 50.29 & 29.0 & 14.51 & $94.9(+)$ \\
\hline $6 \mathrm{D}(6 \mathrm{~B})$ & 807.5 & 29.96 & 27.0 & 8.20 & $96.4(+)$ \\
\hline $7 \mathrm{D}(7 \mathrm{~A})$ & 1396.2 & 46.12 & $30.3(+)$ & 14.83 & 90.1 \\
\hline LSD & 126.2 & 4.30 & 0.1 & 1.20 & 0.8 \\
\hline
\end{tabular}


Phosphorus utilization efficiency (PUE): Variability of the parameter was noticeably higher than for NUE and number of lines with positive reaction was higher than for the other analyzed indices. Only two lines of 'Presto', namely 1D(1A) and $2 \mathrm{D}(2 \mathrm{~A})$, showed significantly lower PUE than the cultivar standard, while six ones: $2 \mathrm{D}(2 \mathrm{~B}), 4 \mathrm{D}(4 \mathrm{~A})$, $4 \mathrm{D}(4 \mathrm{~B}), 5 \mathrm{D}(5 \mathrm{~A}), 6 \mathrm{D}(6 \mathrm{~A})$ and $6 \mathrm{D}(6 \mathrm{~B})$ were significantly more effective. The majority of substitutions in 'Rhino' showed a significant negative effect, while $4 \mathrm{D}(4 \mathrm{~A}), 4 \mathrm{D}(4 \mathrm{~B}), 6 \mathrm{D}(6 \mathrm{~A})$ and $6 \mathrm{D}(6 \mathrm{~B})$ substitutions caused a significant PUE increase. The PUE for $5 \mathrm{D}(5 \mathrm{~A})$ line was on the level of the 'Rhino' standard.

\section{Discussion}

The most interesting substitutions which result in improvement of $\mathrm{N}$ and $\mathrm{P}$ management in the triticale seedlings proved to be $5 \mathrm{D}(5 \mathrm{~B})$ and $4 \mathrm{D}(4 \mathrm{~B})$. The plant vigor was not reduced, in contrast to majority of other chromosome replacements. In 'Presto' the increases of dry matter, in relation to that of standard cultivar, were significant (by ca. $19 \%$ and $11 \%$, respectively). Accumulation of nitrogen and phosphorus was mainly a function of plant dry matter (the correlation coefficients $r=0.996$ and $r=0.977$, respectively). The NUE and PUE parameters were correlated negatively with the dry matter $(r=-0.183$ and $r=-0.634$, respectively), however more variation was left for the more specific effects. The highest increase of NUE has been noted in the 'Rhino' 5D(5B) - by about 7\%. The comparison of performance of $5 \mathrm{D}(5 \mathrm{~B})$ and $5 \mathrm{D}(5 \mathrm{~A})$ lines suggests importance of the 5D per se in 'Rhino' cultivar, while in 'Presto' cv. significance of replaced A or B chromosome can be seen. The PUE values for 4D(4B) in both 'Presto' and 'Rhino' substitutions were significantly higher than in the standards (by ca. 13\% and $11 \%$, respectively). The lowest level of plant vigor and $\mathrm{N}$ and $\mathrm{P}$ accumulation in the $4 \mathrm{D}(4 \mathrm{~A})$ substitutions of both sets can be attributed to large structural differences between the 4D substituting and the 4A substituted chromosomes due to the known 4AL-5AL and 4A-7B heterologous translocations (Naranjo et al., 1987, Cao et al., 1989, Nelson et al., 1995). Thus, the high usefulness of 4D could be expressed only in the 4D(4B) substitutions. Probably the same cause makes production of the 'Rhino' 7D(7B) line difficult. The highest PUE seems to be correlated with presence of the 4D rather than with absence of 4A or 4B. Our previous investigation on the $\mathrm{D}(\mathrm{R})$ substitutions (Oracka, Łapiński, 2006) indicated extremely positive effects of the 4D"(4R') incomplete substitution (with one rye chromosome maintained) in 'Rhino' on the parameters studied, which confirms high value of the 4D chromosome in engineering of environment friendly triticale. In the research of Budzianowski and Woś (2004) the chromosomes $4 \mathrm{D}$, in the same $4 \mathrm{D}(4 \mathrm{~A})$ and $4 \mathrm{D}(4 \mathrm{~B})$ substitution lines, were among the most efficient in rising tolerance to high concentration of aluminium ions.

The highest accumulation of the nutrients has been found in the $3 \mathrm{D}(3 \mathrm{~A})$ line of 'Rhino', together with high scores for plant dry matter. It is inconsistent with the results in our paper mentioned above, which shows that the 'Presto', not the 'Rhino' gene background contributes to the $3 \mathrm{D}$ chromosome superiority in the $\mathrm{N}$ and $\mathrm{P}$ accumulation when substituted for the $3 \mathrm{R}$. The difference cannot be attributed to different allelic composition of the 3D chromosome, which was introduced from the wheat cultivar 'Grana' (Lukaszewski 1990, Budak et al. 2004). The 6D(6A) substitution of 'Rhino' did not show as significant and complex effect on nutrients management as the $5 \mathrm{D}(5 \mathrm{~B})$ and $4 \mathrm{D}(4 \mathrm{~B})$, however the PUE level was slightly increased without negative side effects on plant dry matter and other parameters studied. The PUE parameter also increased in $6 \mathrm{D}(6 \mathrm{~B})$, but the plant vigor was much lower. The results for both $6 \mathrm{D}(6 \mathrm{~A})$ and $6 \mathrm{D}(6 \mathrm{~B})$ substitutions indicate that presence of the $6 \mathrm{D}$ chromosome rather than absence of the $6 \mathrm{~A}$ or $6 \mathrm{~B}$ is responsible for PUE increase. The $6 \mathrm{D}(6 \mathrm{R})$ substitution of rye chromosome (from our earlier studies) also exerted positive effect on the PUE and NUE parameters (Oracka, Łapiński, 2006). The PUE and plant dry matter were remarkably high also in the $2 \mathrm{D}(2 \mathrm{~B})$ substitution of 'Presto'. The low values in 'Rhino' $2 \mathrm{D}(2 \mathrm{~B})$ show importance of differences in varietal background. The possible influence of different 2D allelic composition has to be excluded here, because in production of the 'Presto' set the substitutions of 'Rhino' served as donors and the same variants of D-chromosomes are present in the respective lines of both sets (Lukaszewski, 1990). High importance of the $2 \mathrm{D}$ chromosome in determination of all parameters studied is confirmed by our earlier results on the $\mathrm{D}(\mathrm{R})$ substitutions in triticale, where the NUE and PUE reach the highest levels in the 2D(2R) line (Oracka, Łapiński 2006). The highest $2 \mathrm{D}(2 \mathrm{~A})$ value for NUE in 'Presto' in the present paper is in agreement with those results.

The $1 \mathrm{D}(1 \mathrm{~A})$ and $7 \mathrm{D}(7 \mathrm{~A})$ 'Rhino' substitutions are also worth of mention as representing relatively high levels of all studied parameters, except for PUE. The respective 'Presto' substitutions performed much worse, suggesting that some 
reserves may exist in recombination between the studied cultivars, even without the D-genome manipulation.

The results presented above show the importance of cultivar genetic background for effective substitution. Comparison of respective 'Presto' and 'Rhino' substitution lines suggests that much more variation is to be discovered in triticale after creation of substitution lines from different sources of $\mathrm{A}, \mathrm{B}$ and $\mathrm{D}$ genomes. A reduction of viability is a rule in substitutions, even on the 6x ploidy level, well buffered by genetic redundancy. The increases of dry matter in 'Presto' 5D(5B) and 4D(4B) seem to contradict this tendency.

However, the field trials performed by Budak et al. (2004) with the same 'Presto' substitution set did not show yield increase in any lines, including those deduced as promising from the presented lab experiment. The discrepancy may be attributed to the environmental circumstances, much different in field than in phytotron hydroponic culture. Another source of differences may be the growth phase difference, the $\mathrm{N}$ an $\mathrm{P}$ metabolism in young plants studied here is not necessarily the same as in the more advanced growth stages. Nevertheless, the results confirm the main idea on the potential for improvement of nutrient management in the $\mathrm{D}(\mathrm{A})$ and $\mathrm{D}(\mathrm{B})$ substitution lines of hexaploid triticale. The identification of most promising substitutions seems also worth of attention, because in our earlier studies the interspecific differences between wheat and triticale, concerning the same parameters studied in the same way on seedlings in phytotron hydroponic, were in agreement with those observed in field practice.

We do not agree with the final suggestion of Budak et al. (2004), that no major benefit can be expected from the D-genome substitutions. Such conclusion cannot be valid as based on the unbalanced cytogenetic stocks where no effort has been put in breeding adjustment of a proper gene background to a particular substitution. Thus, only the bred forms of substituted $2 \mathrm{D}(2 \mathrm{R})$ spring triticales of Mexican origin show high yield potential, particularly on alkaline soils, where they outyield the non-substituted forms with complete rye genome (Royo et al. 1993). Considering that evolutionary distance between the $\mathrm{D}$ genome and its A or B relatives is lower than between the $\mathrm{D}$ and $\mathrm{R}$ genomes, one could expect less difficulties in breeding adjustment and development of a $\mathrm{D}(\mathrm{A})$ or $\mathrm{D}(\mathrm{B})$ whole chromosome substitution cultivar.

As known from wheat breeding, chromosome arms have more chances for successful assimila- tion into breeding populations than whole alien chromosomes. The 1RS.BL and 1RS.AL translocations in bread wheat are the examples of such chromosome arm replacement resulting from the frequently made triticale-wheat crosses. The 1RS arm was spontaneously and widely included into the breeding populations because of its effect on adaptation to adverse environmental conditions (Lukaszewski 1990b, Hoffmann 2008). Crosses between whole chromosome substituted and non-substituted forms produce relatively frequent centromeric translocations (Friebe et al. 2005). The same could be expected for the chromosome arms of D-genome positively affecting management of mineral nutrients.

Introduction of the D-genome chromosomes into hexaploid triticale is worth of effort considering other possible advantages detected by other authors. The 5D chromosome in triticale controls better frost tolerance (Sutka and Snape, 1989) and increases grain hardness (Campbell et al. 1999). In the research of Budzianowski and Woś (2004) the chromosomes $4 \mathrm{D}$ and $6 \mathrm{D}$, from the same sets of substitution lines, were among the most efficient in rising tolerance to high concentration of aluminium ions. Another advantage of the 6D incorporation into triticale may be improvement of baking quality (Payne, 1987). Additionally, the presence of D-genome chromosomes in triticale could enable access, via the Triticum aestivum bridge, to wide variation of the wild D-genome progenitor - Triticum tauschii, which is being recently extensively explored as a source of biotic and abiotic stress resistance for bread wheat (Mujeb-Kazi 2008). The T. tauschii is mentioned also by Huang et al. (2007) as a species containing genes responsible for high nutrient utilization efficiency.

\section{Conclusions}

The results confirm usefulness of homeologous substitution of whole chromosomes as a tool for improvement of multigenic traits in alloploid species.

The $4 \mathrm{D}(4 \mathrm{~B})$ substitution proved to be most effective in improvement of nitrogen and phosphorus management in Rhino (spring) and Presto (winter) cultivars of hexaploid triticale, whereas $3 \mathrm{D}(3 \mathrm{~A})$ and $5 \mathrm{D}(5 \mathrm{~B})$ positive effects were observed in Rhino and Presto, respectively.

The effects of particular chromosome substitutions were frequently specific to the cultivar sets in which they were present. 


\section{Literature}

Alam, S. M., 2001. Genetic variations in nutrient contents by wheat and its substitution lines. Pakistan Journ. of Biol. Sci. 4, 642-644.

Baligar, V. C., N. K. Fageria, and Z. L. He, 2001. Nutrient use efficiency in plants. Comm. Soil Sci. Plant Anal. 32 (7), 921-950.

Budak, H., P. S. Baenzinger, B. S. Beecher, R. A. Graybosch, T. Campell, J. Shipman., M. Erayman., K. M Eskridge, 2004. The effect of introgressions of wheat D-genome chromosomes into 'Presto' triticale. 2004. Euphytica 137, 261-270.

Budzianowski, G. and H. Woś, 2004. The effect of single D-genome chromosomes on aluminium tolerance of triticale. Euphytica 137, 165-172.

Campbell, K. G., B. C. Bergman, D. C. Gualberto, J. A. Anderson, M. J. Giroux, G. Hareland, R. G. Fulger, M. E. Sorrels and P. L. Finney, 1999. Quantitative trait loci associated with kernel traits in a soft and hard wheat cross. Crop. Sci. 39, 1184-1195.

Cao, S., P.J. Sharp, A. J. Worland, E. J. Warham, R. M. D. Koebner and M.D. Gale, 1989. RFLP-based genetic maps of wheat homoeologous group 7 chromosomes. Theor. Appl.Genet. 78, 495-504.

Ciepły, J., and T. Oracka, 2001. Genetic Differences for Nutrients Utilization Efficiencies in Winter Triticale and Spring wheat. W.J. Horst (Ed.), Plant nutrition - Food security and sustainability of agro-ecosystems. 96-97, Kluwer Academic Publishers.

Friebe, B., P. Zhang, G. Linc, and B. S. Gill, 2005. Robertsonian translocations in wheat arise by centric misdivision of univalents at anaphase I and rejoining of broken centromeres during interkinesis of meiosis II. Cytogenet. Genome Res. 109 (1-3), 293-297.

Górny, A. G. 2000. Effects of the substituted A and B chromosomes of Triticum dicoccoides on the nitrogen, phosphorus and water use efficiencies in the 'Langdon' durum wheat (T. turgidum L. var. durum). Cereal Research Communications Vol. 28 No. 3 pp. 293-298

Hoagland D.R., and D.I. Arnon. 1950. The water-culture method for growing plants without soil. California Agricultural Experiment Station. Circular 347.
Hoffmann, B., 2008. Alteration of drought tolerance of winter wheat caused by translocation of rye chromosome segment 1RS. Cereal Res. Comm. 36(2), 269-278.

Huang, M .L., X . P. Deng, Y. Z. Zhao, S. L. Zhou, S. Inanaga, S. Yamada, and K. Tanaka, 2007. Water and nutrient use efficiency in diploid, tetraploid and hexaploid wheat. J. Integr. Plant Biol. 49(5), 706-715.

Lukaszewski, A. J., 1990a. Development of aneuploid series in hexaploid triticale. Proc. $2^{\text {nd }}$ Int.Triticale Symp, 1-5 October, Passo Fundo, Rio Grande do Sul, Brazil, 397-400.

Lukaszewski A. J., 1990b. Frequency of 1RS.AL and 1RS. BL translocations in United States wheats. Crop Sci. 30, 1151-1153.

Mujeeb-Kazi, A., A.Gul, M. Forooq, S. Rizwan, I. Ahmad, 2008. Rebirth of synthetic hexaploids with global implications for wheat improvement. Austr. J. Agric. Res. 59(5): 391-398.

Naranjo, T., A. Roca, P. G. Goicoecha, and R. Giraldez, 1987. Arm homoelogy of wheat and rye chromosomes. Genome 29, 873-882.

Nelson, J. C., M. E. Sorrels, A. E. van Deynze, Y. H. Lu, M. Atkinson, M. Bernard, P. Leroy, J. D. Faris, and J. A. Anderson, 1995. Molecular mapping of wheat: Major genes and rearrangements in homoeologous groups 4, 5 and 7. Genetics 141, 721-731.

Oracka, T., and B. Łapiński, 2005. Plant dry matter and root size in $\mathrm{D}(\mathrm{R})$ substitutions lines of hexaploid triticale. Plant Breed. Seed Sci. 52, 17-30.

Oracka, T., and B. Łapiński, 2006. Nitrogen and phosphorus uptake and utilization efficiency in $\mathrm{D}(\mathrm{R})$ substitution lines of hexaploid triticale. Plant Breeding 125, 221-224.

Paponov, I. A., S. Lebedinska, and E. I. Koshkin, 1999. Growth analysis of solution culture-grown winter rye, wheat and triticale at different relative rates of nitrogen supply. Annals of Botany 84, 467-473.

Payne, P. I., 1987. Genetics of wheat storage proteins and the effect of allelic variation on breadmaking quality. Annu. Rev. Plant Physiol. 38, 141-153.

Royo, C., A. Rodriguez, and I. Romagosa, 1993. Differential adaptation of complete and substituted triticale. Plant Breeding 111 (2), 113-119. 